\title{
Factors Influencing Prenatal Care Behaviour of Pregnant Women In Kembaran II Primary Health Center
}

\author{
Ade Lies Oktorita ${ }^{1}$, Elviera Gamelia ${ }^{2}$, Dyah Umiyarni Purnamasari ${ }^{2}$, and \\ Dewi Susanna ${ }^{3}$ \\ ${ }^{1}$ Postgraduate Student Faculty of Public Health, Universitas Indonesia, Depok, Indonesia \\ ${ }^{2}$ The Study Programs of Public Health, Faculty of Health Science, University of Jenderal \\ Soedirman, Purwokerto, Indonesia \\ ${ }^{3}$ Faculty of Public Health, Universitas Indonesia, Depok, Indonesia
}

Corresponding Author:

Ade Lies Oktorita

ade.lies@ui.ac.id

Received: 26 December 2018

Accepted: 23 February 2019

Published: 7 March 2019

Publishing services provided by

Knowledge E

(c) Ade Lies Oktorita et al. This article is distributed under the terms of the Creative Commons

Attribution License, which

permits unrestricted use and

redistribution provided that the

original author and source are credited.

Selection and Peer-review under the responsibility of the 2 nd International Meeting of Public Health 2016 Conference Committee.

\section{Abstract}

Pregnancy is a natural process that will be experienced by women that takes within 280 to 300 days. During pregnancy the pregnant woman requires proper supervision. Kembaran II Primary Health Center in 2014 had 3 cases of maternal mortality, and the number of high-risk pregnant women was $48 \%$. The purpose of this research was to analyze the factors that influenced to prenatal care behavior of pregnant women in Kembaran II Primary Health Center. This research used a quantitative cross-sectional approach. The population of study was 102 pregnant women. Sampling technic used Simple Random Sampling to third-trimester pregnant women, and the sample was 80 people. Data collection was performed by interviewing and questionnaire. To analyze the data, comprise of univariate, bivariate, it used chi-square and for multivariate, it used regression logistics test. Univariate test showed the majority of respondents were in no risk of age $(78.8 \%)$, the level of primary education (55\%), primiparous parity pregnancies (35\%), did not work (58.8\%), per capita income (<IDR 574.923) (8.8\%), had a good knowledge (7.5\%), had right attitude (56.3\%), good family support (57.5\%), information exposure (67.5\%) and inadequate prenatal care behavior (51.3\%). Bivariate test results showed information exposure related to fetal care behavior $(p=0.013)$. The results of multivariate test showed that the variables of family support $(p=0.009)$ and information exposure $(p=0.045)$ affected the prenatal care behavior of pregnant women in Kembaran II Primary Health Center. Information about prenatal care, especially personal hygiene, pregnancy crisis, consumption of nutrients should be increased.

Keywords: Pregnant women; prenatal care behavior; information exposure; family support

\section{Introduction}

Pregnancy is a natural process that will be experienced by every woman that takes place within 280 to 300 days or 39-40 weeks. During pregnancy, the pregnant woman requires proper supervision (Manuaba et al. 2006). Prenatal or Antenatal period needs requires

\section{G OPEN ACCESS}


proper guidance to prevent pregnancy problems as pregnancy, birth, and postpartum that can cause maternal and infant mortality (Bobak et al. 2005).

The Maternal Mortality Rate is indicator of health development and fulfillment to women reproduction right. Kembaran II Primary Health Center had a reasonably high MMR in the district of Banyumas. In 2014, there were three maternal deaths the number of high-risk pregnant women, about 48\% (Profil Kesehatan Ibu Kabupaten Banyumas, 2014). Prenatal care is influenced by predisposing, enabling and reinforcing factors, due to mother does not know about prenatal care, maternal attitude or there is no health behavior yet (Notoatmodjo, 2005). Based on Gamelia et al. (2013) research in Ajibarang I Primary Health Care, maternal care was influenced by pregnancy age, cover a distance to health center, and husband role. Based on other research doing by Erlindawati et al. (2008) showed exposure information related to antenatal care advantage in Aceh Besar, Nanggro Aceh Darussalam. Based on background, a researcher interested to know about the factors that influence to prenatal care behavior of pregnant women in Kembaran II Primary Health Center.

\section{Methods}

This research used a quantitative cross-sectional approach. The population of study was 102 pregnant women. Sampling technic used Simple Random Sampling to thirdtrimester pregnant women, and the obtained sample was 80 people. Data collection was performed by interviewing using questionnaire and secondary data from Kembaran II Primary Health Center. Data collection was completed by talking using a survey containing are age, the level of primary education, primiparous parity pregnancies, work, per capita income, knowledge, attitude, family support, and information exposure. Data were analyzed by using SPSS program. Univariate analysis was used to know general description, bivariate used chi-square to know about relation and multivariate used regression logistics test to know about influence factors of behavior.

\section{Results}

Results of univariate analysis using frequency distribution showed majority of respondents was in no risk of age (78.8\%), had level of basic education (SD and SMP) (55\%), had Primiparous Parity Pregnancies (35\%), not work (58.8\%), and had less than (<IDR 574.923) (8.8\%). From 80 respondents, the majority of respondents had good knowledge (57.5\%), good attitude (56.3\%), good family support (57.5\%), the majority of respondent 
had exposure information (67.5\%), had poor prenatal care behavior (51.3\%). Bivariate analyze using chi-square showed that exposure information variable had a $p$ value $<0.05$, showing there was a relation between exposure information and prenatal care behavior in Kembaran II Primary Health Center. Multivariate analyze using regression logistics test showed exposure information variable $(p=0.009)$ and family support variable $(p=$ 0.045 ) had $p$-value $<0.05$. That exposure information variable and family support had influenced the prenatal care behavior of pregnant women in Kembaran II Primary Health Center.

\section{Discussion}

The result showed that the exposure information variable had affected the prenatal care behavior of pregnant women ( $p$ value $=0.009$ ) in multivariate analysis. The results were consistent with research conducted by Erlindawati et al. (2008), stating that exposure of information affected the use of antenatal care to pregnant women in Aceh Besar with $p=0.015$. Most of the pregnant women had been getting information about pregnancy care including the dangers of smoking in pregnancy (95\%), the best exercise for pregnant women during pregnancy (92.5\%) as well as information regarding taking a nap that was good for pregnant women (90\%). The results of the bivariate analysis showed that of 54 pregnant women who exposed to information were 32 pregnant women (59.3\%) had good behavioral in pregnancy treatments, in line with WHO theory in Notoatmodjo (2007) which stated that the provision of information was one of behavior change strategy in the health program. According to Snehendu B. Kar in Notoatmodjo (2007), the presence or absence of information about health or health care facilities affected a person's behavior. Sources of information obtained by pregnant women came from health professionals, print media, electronic media and others (friend, a health volunteer, family, etc.). Based on the research questionnaire, it's said that pregnant women got information from health workers such as antenatal care (51.3\%), the dangers of smoking on pregnancy (40\%), TT immunization (73.8\%), taking a nap was kind to pregnant women (56.3\%), the benefits of folic acid $(52.5 \%)$, breast care $(45 \%)$, exercising for pregnant women (61.3\%), cleanliness the female organs (61.3\%), sexual activity (53.8\%), cutting the nails (26.3\%), taking bath twice a day (32.5\%) and replacing underwear at least 2 times a day (41.3\%).

Family support variables showed that it had affected the prenatal care behavior of pregnant women with $\mathrm{p}=0.045$ in the multivariate analysis. The results were consistent with research conducted by Gamelia et al. (2012) which stated that the husband's family support, especially support influenced the behavior of the mother's pregnancy 
care in Puskesmas I Ajibarang Banyumas with $\mathrm{p}=0.003$. Based on data obtained from the questionnaire, it's known that a pregnant mother's family always listened to any complaints about the pregnancy (91.3\%), the family still provided nutritious meals for pregnant women (81.3\%) and family always told mothers about the dangers smoking on the safety of the baby in the womb (78.8\%). This was consistent with the theory of Snehendu B. Kar in Notoatmodjo (2003) which stated that the behavior of a person's health was determined partly by the presence or absence of the support of the surrounding community (social assistance). Based on the survey results, it revealed that out of 46 mothers pregnant who had good family support were 27 mothers expectant (58.7\%) that had a good pregnancy care behavior, showing that the greater family support, the better ssimilarly behavior of pregnant women. Most pregnant women were always being told by a family that pregnancy tests should be conducted at least twice during pregnancy (72.5\%). It's supported by behavior respondents always checking the health to healthcare (95\%). Family support was one factor that contributed to an essential role in determining the health status of mothers. Families, especially husbands, often acted as a "gatekeeper" for the search and the use of health services for his wife and family (UNFPA 2004).

\section{Conclusions}

The results showed that the factors that influenced the behavior of prenatal care to pregnant women in Kembaran II Primary Health Care were exposure information and family support. Variables that were not influential were age, parity, education level, occupation, income, knowledge, and attitudes.

Suggestion for pregnant women, it's necessary for them to be more active to access information independently about pregnancy care in particular about hygiene personal, $\mathrm{TT}$, nutrient consumption for pregnant women, physical activity, the gravity of the pregnancy from various sources. It's not only from midwives, but also can be from any media (books, leaflets, newspapers, magazines, television, internet, radio, etc.), health volunteers, friends, family, etc.

\section{References}

[1] Afiyanti, Y. 2004. "Studi Fenomenologi tentang Pengalaman Wanita di Daerah Pedesaan dalam Menjalani Masa Kehamilan Pertama”. Jurnal Keperawatan, Vol 2 , Tahun 2004, Halaman 62-68. 
[2] Bobak, I.M., Lowdermilk, D.L \& Jensen, M.D. 2005. Buku Ajar Keperawatan Maternitas. Edisi 4. EGC: Jakarta

[3] Dinas Kesehatan Banyumas. 2013. Profil Kesehatan Kabupaten Banyumas. Purwokerto.

[4] Dinas Kesehatan Kabupaten Banyumas. 2014. Profil Kesehatan Ibu dan Anak Kabupaten Banyumas Tahun 2014. Banyumas.

[5] Erlindawati, Chompikul J. And Isaranung S. 2008. "Factors Related to The Utilization of Antenatal Care Service among Pregnant Woman at Health Centers in Aceh Besar District, Nanggro Aceh Darussalam, Indonesia." Journal of Public Health and Development, Vol.6 No. 2.

[6] Friedman, Marilyn M. 2005. Keperawatan Keluarga Teori dan Praktik. Edisi 3. EGC: Jakarta.

[7] Gamelia, E., C. Sistiarani dan S. Masfiah. 2013. "Determinan Perilaku Perawatan Kehamilan." Jurnal Kesehatan Masyarakat Nasional Vol. 8, No. 3, Oktober 2013.

[8] Halim, N, Bohara, A. K, dan Ruan, X. 2010. "Healthy Mother, Healthy Children: Does Maternal Demand for Antenatal Care Matter for Child Health in Nepal?." Health Policy Plan. Vol 26 (3), 2015: 242-256.

[9] INFID. 2013. Membedah angka kematian Ibu: Penyebab dan Akar Masalah Tingginya Angka Kematian Ibu. Institut KAPAL. Jakarta Selatan.

[10] Kementrian Kesehatan RI, 2010. Rencana Operasional Promosi Kesehatan Ibu dan Anak. Pusat Promosi Kesehatan Republik Indonesia. Jakarta.

[11] Kementrian Kesehatan RI, 2010. 2014.Profil Kesehatan Indonesia 2013. Jakarta.

[12] Magadi M.A., Madise N.J. \& Rodrigues R.N. 2002. "Frequency and timing of Antenatal Care in Kenya; Explaining The Variations Between Women of Different communities." Social Science \& Medicine: 51 (4): 551-561.

[13] Manuaba, I.B.G., I.A. Chandranita Manuaba dan I.B.G. Fajar Manuaba. 2006. Buku Ajar Patalogi Obstetri untuk Mahasiswa Kebidanan. Cetakan I. Penerbit Buku Kedokteran EGC: Jakarta.

[14] Notoatmodjo, S. 2003. Pendidikan Kesehatan dan Perilaku Kesehatan. Rineka Cipta: Jakarta.

[15] Notoatmodjo, S. 2005. Promosi Kesehatan Teori dan Aplikasi. Rineka Cipta: Jakarta.

[16] Notoatmodjo, S. 2007. Kesehatan Masyarakat, IImu dan Seni. Rineka Cipta: Jakarta.

[17] United Nations Fund for Population Activities. 2004. Saving Mothers' Lives The Challenge Continues.http://www.unfpa.org/sites/default/files/pub-pdf/ savingmotherslives.pdf. (Accessed 1 Agustus 2015. 
[18] Wahida. 2000. Faktor-faktor yang Berhubungan dengan Pemanfaatan Pelayanan Antenatal di Puskesmas Marawola Kabupaten Donggala. [Undergraduate Thesis]. FKM Universitas Hasanudin: Makasar.

[19] Yenita, S. 2012. Faktor Determinan Pemilihan Tenaga penolong Persalinan di Wilayah Kerja Puskesmas Desa baru Kabupaten Pasaman Barat Tahun 2011. [Thesis]. Universitas Andalas. 